\title{
Tyrphostin Compound
}

National Cancer Institute

\section{Source}

National Cancer Institute. Tyrphostin Compound. NCI Thesaurus. Code C1757.

Any of a class of synthetic protein tyrosine kinase inhibitors based on the structure of

Erbstatin, a compound initially isolated from Streptomyces MH435-hF3 that inhibits the autophosphorylation of the receptor for epidermal growth factor. 